\title{
HUBUNGAN ASERTIVITAS DAN MOTIVASI DENGAN KETERAMPILAN MANAJEMEN WAKTU DALAM PENYUSUNAN SKRIPSI MAHASISWA
}

\author{
Siti Zulfa Afriyana ${ }^{\left.1^{*}\right)}$, Mulyati ${ }^{1}$, Hamiyati ${ }^{1}$ \\ ${ }^{1}$ Program Studi Pendidikan Kesejahteraan Keluarga, Fakultas Teknik, Universitas Negeri Jakarta, \\ Jakarta Timur 13220, Indonesia \\ *) E-mail: afriyanas18@gmail.com
}

\begin{abstract}
Abstrak
Penelitian ini bertujuan untuk memperoleh gambaran tentang hubungan asertivitas dan motivasi dengan keterampilan manajemen waktu dalam penyusunan skripsi pada mahasiswa akhir. Terdapat mahasiswa di Fakultas Teknik, Universitas Negeri Jakarta yang masih belum lulus dalam 4 tahun salah satunya kurangnya mengatur waktu dalam menyusun skripsi, hal itu disebabkan karena kurangnya ketegasan diri dan motivasi dalam diri. Penelitian ini dilaksanakan di Universitas Negeri Jakarta. Metode penelitian ini menggunakan metode survei. Populasi pada penelitian ini adalah mahasiswa fakultas teknik di Universitas Negeri Jakarta dengan jumlah sampel sebesar 177 responden. Teknik pengambilan data menggunakan simple random sampling. Uji hipotesis data yang digunakan adalah korelasi koefisien product moment dengan 2 hasil yang disimpulkan $r_{\text {hitung }}>r_{\text {tabel }}$ dari assertivitas dengan keterampilan manajemen waktu yaitu sebesar 0,274 $>0,143$ dan $r_{\text {hitung }}>r_{\text {tabel }}$ dari motivasi dengan keterampilan manajemen waktu yaitu sebesar $0,455>0,143$. Hasil uji t dengan taraf signifikan 0,05 diperoleh $t_{\text {hitung }}>t_{\text {tabel }}$ yaitu 6,74 $>1,65$ dari variabel assertivitas dengan keterampilan manajemen waktu dan $t_{\text {hitung }}>t_{\text {tabel }}$ yaitu 3,64 $>1,65$ dari variabel motivasi dengan keterampilan manajemen waktu, hasil ini menjelaskan bahwa terdapat korelasi positif dan hubungan yang signifikan antara assertivitas dan motivasi dengan keterampilan manajemen waktu. Assertivitas dan motivasi memberikan sumbangan efektif masing-masing dengan keterampilan manajemen waktu sebesar $21,3 \%$ dari assertivitas dan 32,9\% dari motivasi sedangkan sisanya 45,8\% ditentukan factor lain yang tidak diteliti.
\end{abstract}

Kata kunci: assertivitas, keterampilan manajemen waktu, motivasi, penyusunan skripsi

\section{The Relationship of Asertivity and Motivation with Time Management Skills in Undergraduate Thesis Preparation}

\begin{abstract}
This study aims to obtain a description of the relationship between assertiveness and motivation with time management skills in thesis preparation for college. The students are from the Faculty of Engineering, State University of Jakarta. The researcher is not graduated yet in 4 years, one of which is the lack of time management in preparing an undergraduate thesis, it is caused by a lack of selfdetermination and motivation. This research was conducted at the Faculty of Engineering, State University of Jakarta. This type of research is associative quantitative. The population in this study were 317 student respondents at the end of 2013 and 2014 at the Faculty of Engineering with a total sample of 177 respondents. Data collection techniques using probability sampling is simple random sampling. The prerequisite test in this study uses the liliefors for the normality test and the linearity regression test. The results show that the data are normally distributed and linear. Hypothesis test data used is the product-moment correlation coefficient with 2 results concluded $r_{\text {count }}>r_{\text {table }}$ from assertivity with time management skills that is equal to 0,274 $>0,143$ and $r_{\text {count }}>r_{\text {table }}$ from support with management by $0,455>0,143$. T test results with a significance level of 0,05 obtained $t_{\text {count }}>$ $t_{\text {table }}$ is $6,74>1,65$ from the assertivity variable with time management skills and $t_{\text {count }}>t_{\text {table }}$ is 3,64 $>1,65$ from the help variable with management skills time, these results explain the positive relationship and the significant relationship between assertiveness and motivation with time management skills. Assertive and motivation contribute each with time management skills of $21,3 \%$ of assertive and $32,9 \%$ of motivation while receiving $45,8 \%$ are determined by factors not examined.
\end{abstract}

Keywords: assertive, motivation, undergraduate thesis preparation, time management skills 


\section{PENDAHULUAN}

Mahasiswa merupakan generasi intelektual dan peserta didik yang terdaftar dalam suatu Perguruan Tinggi. Mahasiswa diharapkan mampu mengembangkan apa yang diterima oleh dosen secara kreatif. Salah satu cara untuk dapat melewati masa studinya dengan mengerjakan skripsi, sebagai tugas akhir yang harus dibuat mahasiswa dalam pengembangan ilmu yang sudah didapat khususnya mahasiswa tingkat akhir. Menurut Agusta (2015) mengatakan bahwa mahasiswa akhir adalah calon lulusan sarjana masa depan yang akan mengembangkan ilmu ke dalam dunia kerja.

Salah satu syarat untuk mendapatkan gelar sarjana mahasidwa harus membuat tugas akhir atau skripsi dan menyelesaikan seluruh mata kuliah yg ada dan harus menempuh studi minimal selama 4 tahun. Menurut Sudarya, Bagia, \& Suwendra (2014) mengatakan bahwa harapan ideal mahasiswa dalam menyelesaikan studi untuk S1 di perguruan tinggi yakni delapan semester, namun masih banyak terdapat keterlambatan dalam menyusun skripsi. Setiap Universitas ingin meluluskan mahasiswa dengan tepat waktu, khususnya di Universitas Negeri Jakarta berusaha untuk dapat meluluskan mahasiswa dengan menempuh studi 4 tahun untuk S1, tetapi dalam hal ini cukup banyak mahasiswa yang belum mampu menyelesaikan studi S1 dalam kurun 4 tahun terutama mahasiswa Fakultas Teknik.

Tabel 1. Mahasiswa Fakultas Teknik 2013 dan 2014

\begin{tabular}{lcc}
\hline \multirow{2}{*}{ Keterangan } & \multicolumn{2}{c}{ Angkatan } \\
\cline { 2 - 3 } & 2013 & 2014 \\
\hline Mahasiswa yang sudah wisuda & 193 & 109 \\
Mahasiswa yang masih aktif & 109 & 208 \\
Jumlah & 302 & 317 \\
\hline
\end{tabular}

Tabel 1 menunjukkan masih terdapat sebanyak 32\% mahasiswa aktif tahun 2013 dan sebanyak 65\% mahasiswa aktif tahun 2014 yang telah mengisi KRS di semester 111 tahun 2019/2020. Hasil studi pendahuluan menunjukkan sebagian besar (60\%) salah satu penyebab keterlambatan dalam penyusunan skripsi antara lain manajemen waktu yang tidak baik. Hal ini menunjukan bahwa manajemen waktu adalah salah satu faktor internal yang di alami oleh mahasiswa khususnya mahasiswa tingkat akhir yang sedang melakukan skripsi, berdasarkan hasil penelitian Aslinawati \& Mintarti (2017) mengatakan bahwa terdapat 201 mahasiswa terlambat dalam menyusun skripsi hal ini sebabkan kurangnya mahasiswa mengatur waktu dengan baik. Oleh karena, masih cukup banyak mahasiswa yang belum mampu mengatur waktu dalam mengerjakan skripsi.. Kurangnya mengatur waktu dengan baik menyebabkan sulitnya mencapai tujuan akhir dengan tepat. Menurut Gea (2014) mengatakan bahwa manajemen waktu adalah pengaturan diri untuk mengatur dan menggunakan waktu secara efektif dan efisien melalui dengan perencanaan dan penjadwalan yang terkontrol. Sulitnya mengatur waktu bagi individu menyebabkan seseorang menjadi sulit untuk mengendalikan perasaan dan berkurangnya ketegasan perilaku dalam mencapai tujuan.

Hasil studi pendahuluan menunjukan selain manajemen waktuyg lemat yang menghambat penyelesaian adalah sebanyak 53,3\% resdonpen menatakan kurangnya motivasi dan kepercayaan diri dan $53.3 \%$ kurangnya seretif pada tujuan hidup sebanyak $53,3 \%$. Hal ini sejalan dengan penelitian yang dilakukan oleh Ramadhani, Zain, \& Marsofiyati (2017) bahwa dengan penilaian dalam diri yang rendah menyebabkan kurangnya kepercayan terhadap dirinya untuk menyelesaikan tugas.

Mahasiswa memerlukan kepercayaan diri yang cukup untuk dirinya. Menurut Ahmed, Abdelazeemel-hosany, \& Mohamed (2016) bahwa " the assertive people able to cope with challenges, manage time well, increase self confidence and increase satisfaction level." Asertif adalah faktor internal dari dalam diri mahasiswa, pengertian asertif tersebut dijabarkan lebih dalam oleh Twenge (2001) mengemukakan pengertian asertif yaitu kebebasan mengutarakan pikiran dan perasaan, penuh kepercayaan diri dan mampu mengarahkan diri 
sendiri. Penelitian sebelumnya yang dilakukan oleh Rizka \& Indarto (2016) bahwa asertivitas memberikan kontribusi sebanyak $14,06 \%$ dalam penyusunan skripsi. Seorang mahasiswa akan merasa termotivasi untuk menentukan ketegasan dalam dirinya. Jika ketegasannya seseorang tinggi akan meningkatkan kepercayaan diri. Dengan demikian, seseorang yang tegas dapat mengatur waktu dengan baik.

Ketika seseorang merasa cemas dan tidak berani mengemukan pendapatnya akan muncul rasa kekhawatiran orang tersebut. Hal ini menjadikan seseorang yang kurang asertif dan memiliki asertivitas yang rendah dan berdampak hal negative dalam dirinya hingga dewasa. Sehingga mahasiswa kehilangan rasa kepercayaan diri untuk bisa tegas terhadap dirinya sendiri dan menyebabkan motivasi menjadi berkurang untuk segera menyelesaikan tujuannya.

Selain faktor dari dalam diri mahasiswa memerlukan perilaku asertivitas, faktor motivasi merupakan faktor yang mempengaruhi dalam manajemen waktu. Hasil penelitian sebelumnya yang dilakukan oleh Azhar \& Ginting (2014) mengatakan adanya hasil yang signifikan dan positif antara lingkungan belajar, manajemen waktu dengan motivasi dan memberikan sumbangan sebanyak 70,4\%. Peranan motivasi, mahasiswa memiliki insiatif dalam mengembangkan aktivitas untuk dapat untuk melakukan penyusunan skripsi. Menurut Sardiman (2011) motivasi adalah serangkaian usaha untuk menggapai sesuatu yang menyediakan kondisi tertentu, sehingga seseorang akan cenderung mau dan ingin melakukan sesuatu, dan bila ia tidak suka, maka akan berusaha untuk meniadakan atau mengelakkan perasaan tidak suka itu. Seseorang yang mempunyai motivasi tinggi memiliki manajemen waktu yang tinggi pula.

Peranan perilaku asertivitas dan motivasi sangat diperlukan dalam kegiatan penyusunan skripsi pada mahasiswa. Mahasiswa bukan lagi seperti remaja yang tidak bisa menentukan dirinya akan sebuah masa depan. Mahasiswa harus bisa bersikap asertif dan mempunyai motivasi untuk segera menyelesaikan studi dengan tepat waktu. Dengan adanya faktor intern yang mempengaruhi kegiatan belajar akan memberikan keterampilan dalam manajemen waktu dengan baik. Manajemen waktu sebagai motor penggerak dan pendorong untuk individu belajar sehingga individu akan lebih bersemangat dan meningkatkan motivasi terhadap diri dalam menyelesaikan studi. Dengan adanya sikap asertivitas dan motivasi untuk segera menyelesaikan skripsinya, mahasiswa akan segera mengatur waktu dengan baik antara belajar dan mengisi waktu luang dengan kegiatan bekerja atau hangout. Tetapi pada kenyataannya, masih banyak mahasiswa Universitas Negeri Jakarta khususnya Fakultas Teknik yang masih aktif dan masih kurang bisa mengatur waktu dengan baik.

Berdasarkan hasil studi pendahuluan dan uraian latar belakang diatas penulis ingin melihat adakah hubungan asertivitas dan motivasi dengan keterampilan manajemen waktu dalam penyusunan skripsi pada mahasiswa akhir 2013 dan 2014 di Fakultas Teknik, Universitas Negeri Jakarta. Oleh karena itu, peneliti mengharapkan dapat memberikan sumbangan untuk pengembangan teori dari ilmu psikologi keluarga untuk bisa percaya diri dan tegas dalam mengatur waktu dengan baik. Dengan demikian, dalam penelitian ini penulis ingin mengetahui adakah hubungan antara asertivitas dan motivasi dengan keterampilan manajemen waktu dalam penyusunan skripsi pada mahasiswa akhir di Universitas Negeri Jakarta.

\section{METODE}

Jenis penelitian adalah penelitian kuantitatif asosiatif. Metode dalam penelitian ini adalah survei korelasional. Menurut Sugiyono (2015) bahwa penelitian survei adalah penelitian yang dilakukan pada jumlah populasi besar maupun kecil, tetapi data yang dipelajari adalah data dari sampel yang diambil dari populasi tersebut. Alasan peneliti mengunakan metode survei dengan pendekatan korelasional adalah agar dapat mengetahui dan ditentukan variabel mana 
yang berkorelasi, untuk mencari ada tidaknya kaitan antara hubungan assertivitas dan motivasi dengan keterampilan manajemen waktu serta untuk mengetahui seberapa erat kaitan antar variabel satu dengan variabel lainnya, penelitian ini menggunakan penelitian survei dengan pendekatan korelasional. Penelitian dilaksanakan di Universitas Negeri Jakarta, penelitian dilaksanakan pada bulan Januari 2020. Populasi sasaran yang digunakan adalah mahasiswa akhir 2013 dan 2014 di Fakultas Teknik yang tergolong masa studi lebih dari 4,5 tahun yang mengisi KRS di semester 111 tahun 2019/2020. Adapun jumlah keseluruhan populasi tersebut 317 mahasiswa. Penelitian ini menggunakan angket atau kuesioner yang dilaksanakan di Universitas Negeri Jakarta berada di Jalan Rawamangun, Jakarta Timur.

Penelitian menggunakan teknik pengambilan data metode probability sampling yaitu simple random sampling. Teknik yang digunakan untuk pengambilan anggota sampel secara acak dari populasi tanpa memperhatikan strata yang ada dalam populasi. Adapun jumlah populasi yang berhasil ditemukan sebanyak 317 responden sampel yang diambil dengan teknik simple random sampling berjumlah 177 responden yang menggunakan rumus slovin. Dalam penelitian ini kesalahan yang digunakan peneliti adalah sebesar $5 \%$ atau 0,05 . Teknik pengolahan data dan analisis data yang dilakukan menggunakan SPSS dan Ms. Excel.

Pernyataan untuk setiap butir dalam kuesioner diukur menggunakan skala likert dengan kuesioner tertutup yaitu 1 sampai dengan 4 poin, dalam hal ini untuk skala terendah yaitu 1 dan untuk skala tertinggi yaitu 4. Instrumen assertivitas digunakan menurut Galassi dalam (Aryaningrat \& Marheni, 2014) yaitu expressing positive feelings, afirmasi diri dan expressing negative feelings terdiri dari 16 butir pernyataan. Kemudian untuk variabel motivasi oleh Sadirman dalam (Suardana \& Simarmata, 2013) yaitu dimensi intrinsik dan dimensi ekstrinsik terdiri dari 10 butir pernyataan, dan untuk variabel keterampilan manajemen waktu menurut (Cemaloğlu \& Filiz, 2010) yaitu time planning, time traps dan time attitude terdiri 14 butir pernyataan.

\section{HASIL DAN PEMBAHASAN}

\section{Karateristik Responden}

Mahasiswa dalam proses pendidikan diharapkan memiliki kemampuan dasar tahap ketrampilan, pengetahuan dan sikap menurut (Maslihah, 2009). Dalam penelitian ini untuk respondennya yaitu mahasiswa akhir yang masih tercatat di KRS semester 111 tahun 2019/2020. Mahasiswa tingkat akhir adalah mahasiswa di tingkat akhir yang sedang melakukan tugas akhir atau skripsi.

Mahasiswa Universitas Negeri Jakarta berjenis kelamin laki-laki dan perempuan, responden 177 mahasiswa tersebar ke beberapa jurusan di Fakultas Teknik terdapat yakni Jurusan Elektronika, Mesin, Sipil dan IKK. Dilihat dari hasil data yang ditemukan bahwa sebagian besar adalah mahasiswa laki-laki sebanyak 105 dan perempuan sebanyak 72 . . Hal ini dikarenakan mahasiswa Fakultas Teknik cenderung lebih banyak laki-laki.

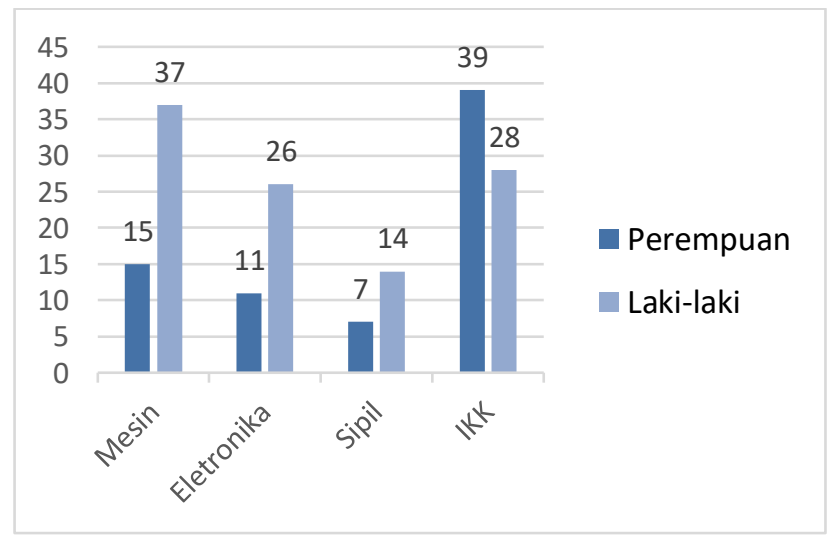

Gambar 1. Diagram Jurusan Responden 
Responden pada penelitian ini berusia 23-26 tahun yang berstatus sebagai mahasiswa aktif yang mengisi KRS semester 111 tahun 2019/2020 angkatan 2013 dan 2014 yang mengambil skripsi. Berdasarkan data, hamper separuh yang berusia 23 tahun responden yang berjumlah 177 mahasiswa sebesar persentase 43\% dan data responden terendah berusia 26 tahun sebesar persentase $8 \%$. Secara lebih lengkap, dan responden berdasarkan usia ditunjukan pada gambar dibawah ini:

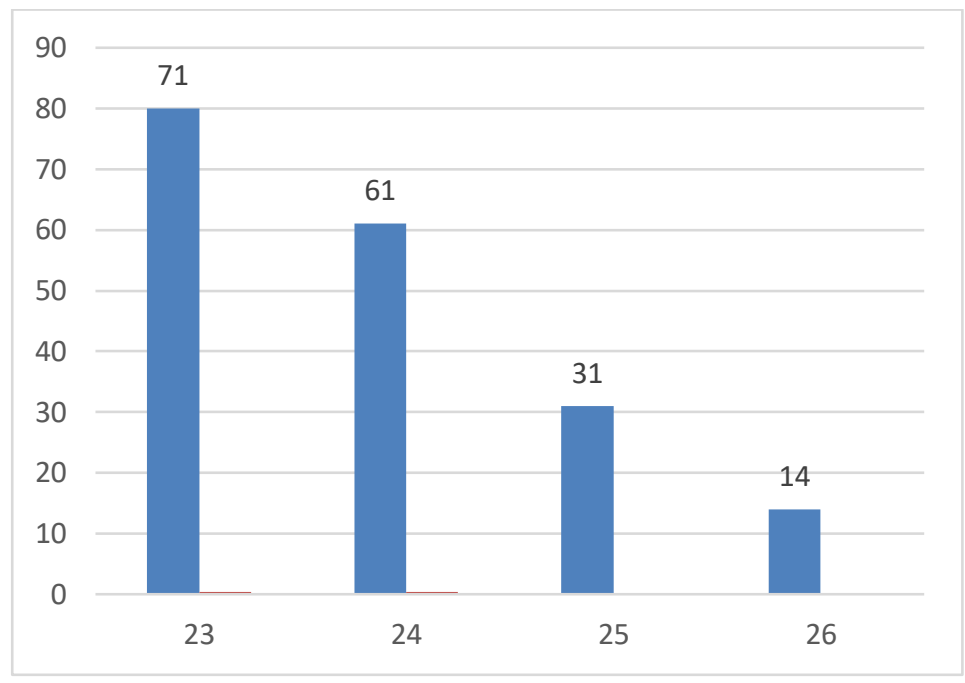

Gambar 2. Diagram Usia Responden

Pada penelitian ini yang dilakukan pada mahasiswa Universitas Negeri Jakarta pada angkatan 2013 dan 2014 dengan 177 responden, Berdasarkan data responden mahasiswa lebih banyak menghabiskan waktu bekerja seperti bekerja fulltime dengan persentase $31,40 \%$. Dengan kegiatan mahasiswa yang hampir separuhnya bekerja harus dapat membagi waktu antara mengerjakan skripsinya dengan pekerjaan, hal ini sesuai menurut (Mardelina \& Muhson, 2017) yaitu mahasiswa harus mampu membagi waktu serta tanggung jawab dalam urusan perkuliahan dan pekerjaan karena mereka harus membagi peran antara sebagai mahasiswa dan pekerja, lain halnya dengan mahasiswa yang tidak bekerja dengan persentase $19,80 \%$ yang masih dapat fokus pada satu kegiatan. Data diatas dapat dilihat pada diagram dibawah ini:

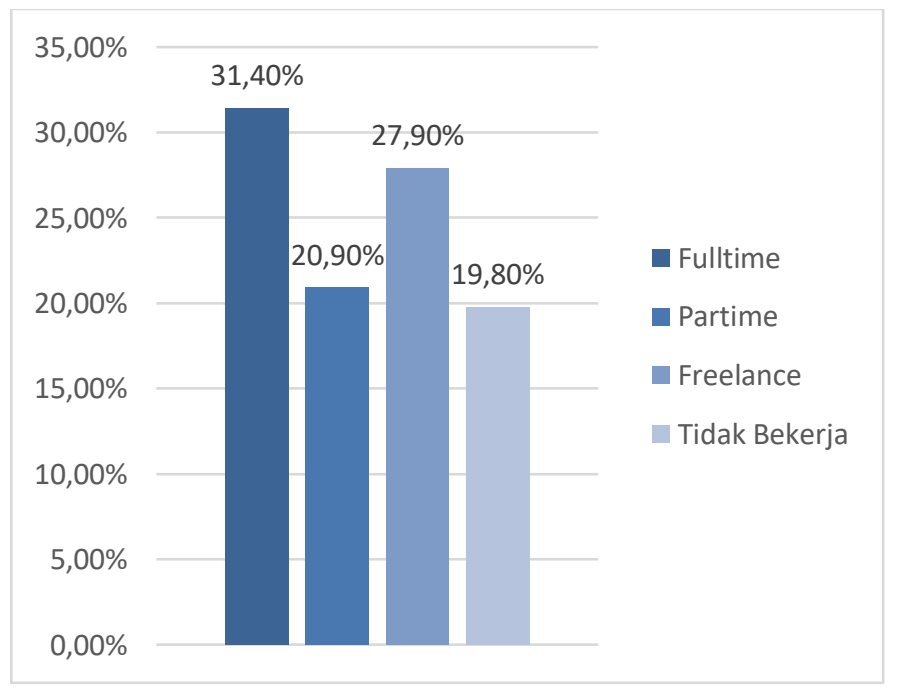

Gambar 3. Diagram Berdasarkan Pekerjaan Responden 


\section{Asertivitas}

Asertivitas ialah perilaku tegas yang timbul karena kebebasan emosi untuk mempertahankan pendapat dan hak pribadinya dalam melakukan komunikasi interpersonal dengan percaya diri dalam mengungkapkan perasaannya menurut Susilawati (2016). Dapat diartikan bahwa assertivitas adalah membangun kemampuan seseorang mengekpresikan diri, pandangan-pandangan dirinya dan menyatakan keinginan dan perasaan secara langsung dengan penuh ketegasan berdasarkan kondisi interpersonal tanpa melanggar hak orang lain. Dimensi yang digunakan dalam pengukuran ini menurut Galassi (1977) yaitu Expressing Positive Feeling, Afirmasi Diri, dan Expressing Negative Feeling.

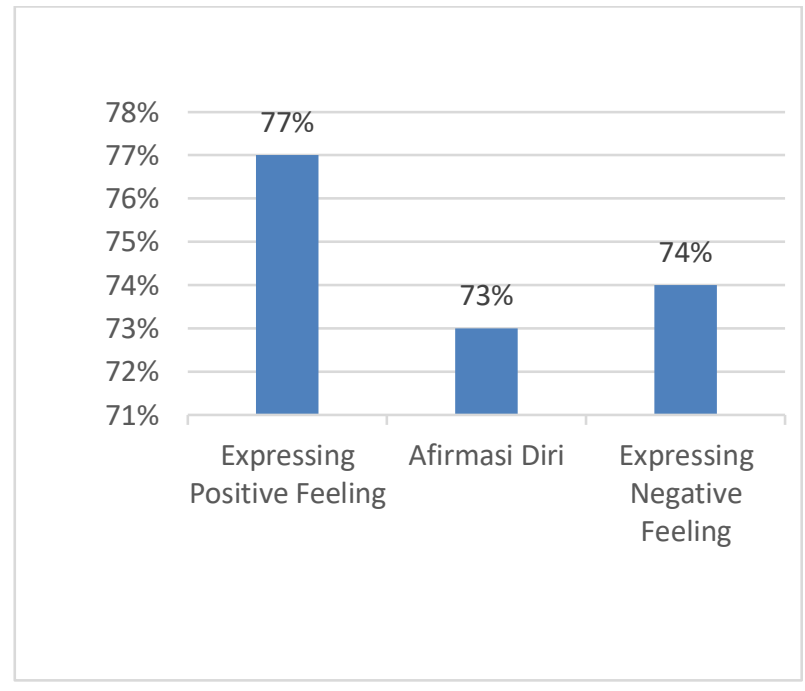

Gambar 4. Diagram Variabel Asertivitas

Hasil penelitian menunjukkan sebagian besar (76\%) mahasiswa mempunyai assertivitas yang tinggi dan mampu mengutaraka pendapat pribadi dengan positif serta negatif tanpa merugikan pihak lain. Hal ini sesuai dengan pendapat Yong (2010) adalah individu yang mampu memberikan mengutarakan dan ekspresi apa adanya, mampu menolak dan menerima dengan baik. Pendapat ini sejalan dengan (Purwanto, 2010) mengatakan bahwa seseorang yang asertif mampu mengekspresikan pernyataan dari minat dan pendapatnya secara bijak adil dan efektif sehingga hal ini dapat dipertahankan dan meningkatkan kepercayaan diri dalam kehidupan sehari-hari.

Untuk persentase dimensi dari variabel asertivitas, dalam dimensi ini terdapat 4 indikator: (1) Dapat Menerima dan Memberikan Pujian, (2) Dapat Menerima dan Menolak Permintaan, (3) Dapat mengungkapkan Perasaan Suka, Cinta dan Sayang dan (4) Dapat Memulai dan terlibat dalam percakapan. Pada variabel Dimensi expressing positive feelings merupakan dimensi tertinggi sebesar $77 \%$ dengan indikator yang membangun perasaan yang menyenangkan dan hal yang positif karena menerima pujian dari oranglain mampu mengutarakan perasaan kepada orang lain dan mampu menghargai orang lain, karena sebuah penghargaan terhadap diri dan orang lain mampu memberikan hal positif dan menumbuhkan sikap asertif. Hal tersebut sesuai dengan pendapat Al'Ain \& Mulyana (2013) secara umum, orang yang asertif dicirikan dengan sikapnya yang jujur, sportif, terbuka, adaptif, aktif, positif dan penuh penghargaan diri sendiri maupun orang lain

Pada variabel assertivitas ini selain dimensi tertinggi terdapat juga dimensi terendah yaitu afirmasi diri. Dimensi asertivitas terdapat 3 indikator: (1) Mempertahankan Pendapat, (2) Menolak Permintaan dan (3) Mengungkapkan pendapat. Hal ini dapat diartikan bahwa seseorang yang mampu bersikap tegas dalam berani mengungkapan pendapat dan tidak menyinggung perasaan dengan penolakan permintaan memiliki arsetif yang cukup baik. Dimensi afirmasi Diri diperoleh persentase sebesar 73\% termasuk kategori cukup tinggi, 
pendapat ini sejalan dengan penelitian Aritonang (2019) bahwa individu yang asertif mampu mengutarakan hal yang ingin disampikan dengan tegas dan jujur tanpa menyinggung perasaan orang lain dan didasari dari opini satu sama lain.

Dimensi Expressing Negative Feeling diperoleh persentase sebesar $75 \%$ adalah kategori cukup tinggi. Dimensi Expressing Negative Feeling terdapat 2 indikator: (1) mengungkapkan ketidaksenangan dan (2) mengungkapkan kemarahan. Hal ini menunjukan bahwa seseorang yang mampu berinteraksi dengan baik dan mampu mengungkapan ketidaksenangan tanpa menyinggung perasaan orang lain adalah termasuk ciri-ciri asertif. Hal ini sesuai dengan penelitian yang dilakukan (Budiyono, 2019) bahwa ciri-ciri perilaku asertif yaitu mampu untuk mengungkapkan pendapat ketidaksenangan tanpa menyakiti orang lain atau dengan kata egois.

\section{Motivasi}

Motivasi adalah suatu kekuatan untuk dapat menggerakan seseroang berperilaku, berpikir dan merasa yang mereka lakukan menurut (Bustan \& Shah, 2014). Pendapat lain dari (Zin, 2001), motivasi merupakan elemen untuk menghasilkan pembelajaran yang sempurna. (Mediawati, 2010) mengemukakan dimensi motivasi yaitu dimensi intrinsik dan ekstrinsik. Dimensi penelitian ini menggunakan alat ukur yaitu dimensi motivasi instrinsik dan dimensi ekstrinsi.

Variabel Motivasi terdapat 2 dimensi yaitu dimensi Instrinsik dan Ektrinsik. Terdapat hasil perolehan variabel motivasi sebesar $72 \%$ dari 177 responden. Menurut Mediawati (2010) dimensi instrinsik merupakan kegiatan belajar yang dimulai berdasarkan penghayatan dorongan diri sendiri yang berkaitan dengan hasil belajar. dan dimensi ekstrinsik merupakan kegiatan belajar yang tumbuh dari dorongan luar dan tidak dari diri sendiri.

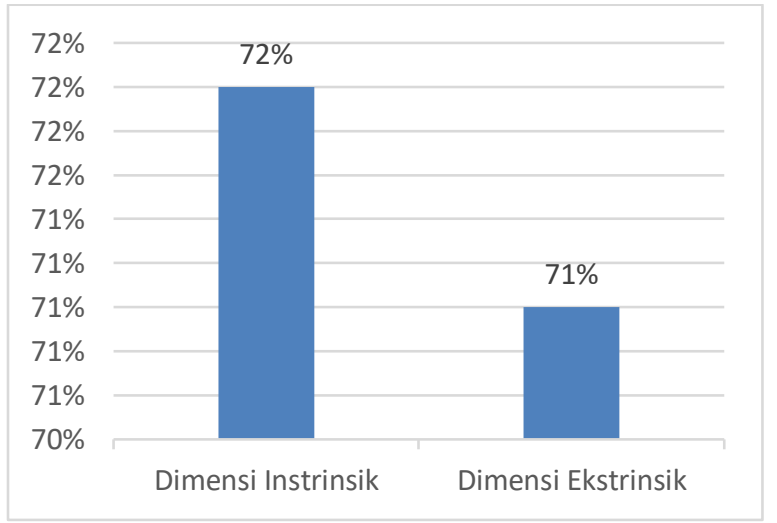

Gambar 5. Dimensi Motivasi

Berdasarkan hasil penelitian variabel motivasi diperoleh hasil sebesar $72 \%$. Dalam dimensi ini terdapat 3 indikator : (1) Adanya Hasrat dan Keinginan untuk berhasil, (2) Adanya dorongan dan kebutuhan dalam belajar, dan (3) Adanya penghargaan dan cita-cita masa depan, dengan dimensi tertinggi yaitu dimensi intrinsik sebesar $72 \%$ dengan indikator yang membangun motivasi dari sendiri untuk berhasil mencapai tujuan yang diinginkan, hal ini sesuai dengan Sardiman (2014) motivasi intrinsik adalah dorongan yang timbul dari diri sendiri untuk melakukan tujuan yang diinginkan.

Pada variabel ini selain dimensi instrinsik tertinggi terdapat juga dimensi terendah yaitu dimensi ekstrinsik. Dalam dimensi ini terdapat 3 indikator yaitu (1) Adanya penghargaan dalam belajar, (2) Adanya kegiatan yang menarik dalam belajar, dan (3) Adanya lingkungan belajar yang kondusif. Dimensi ekstrinsik diperoleh persentase sebesar $71 \%$ termasuk kategori cukup tinggi. Menurut Mediawati (2010) motivasi ekstrinsik merupakan kegiatan belajar yang tumbuh dari dorongan luar yang bukan berasal dari diri sendiri dan tidak mutlak berhubungan dengan 
kegiatan belajarnya sendiri. Karena motivasi ekstrinsik cenderung bersifat semu dan kurang berhubungan langsung dengan keinginan sendiri.

\section{Keterampilan Manajemen Waktu}

Keterampilan manajemen waktu adalah memanfaatkan sebuah waktu dengan baik melalui perencanaan yang mata dan terorganisir. Mengenai aspek-aspek yang mempengaruhi manajemen waktu yang diusulkan oleh (Britton, B.K., \& Tesser, 1991) yang memiliki skala yang bernama "Time Management Questionnair". Time Management Skill memiliki 3 aspek yaitu: (1) Time Planning, (2) Time Traps dan (3) Time Attitude. Pada variabel Keterampilan Manajemen Waktu terdapat 3 dimensi yaitu dimensi Time Planning, Time Traps dan Time Attitude. Terdapat hasil perolehan variabel Keterampilan Manajemen Waktu sebesar $73 \%$ dengan hasil yang cukup tinggi.

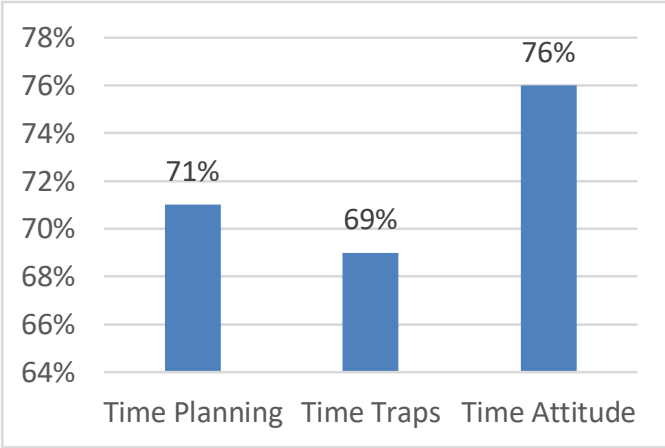

Gambar 6. Dimensi Keterampilan Manajemen Waktu

Berdasarkan perolehan data yang dilakukan variabel keterampilan manajemen waktu diperoleh hasil $73 \%$ dengan Dimensi Time Attitude diperoleh persentase sebesar $76 \%$ termasuk kategori cukup tinggi. Dalam dimensi ini terdapat 1 indikator: (1) Memperhatikan perencanaan kegiataan dan meluangkan banyak waktu melakukan aktivitas yang sudah direncanakan. Dapat dikatakan bahwa Time attitude yang berhubungan pada perencanaan waktu akan memudahkan untuk menggunakan waktu yang efisien agar dapat mencapai tujuan yang sudah direncanakan. Hal tersebut sesuai penelitian Cemaloğlu \& Filiz (2010) penggunaan waktu yang efisien mengurangi kecemasan dan meningkatkan kesuksesan.

Dimensi Time Planning diperoleh persentase sebesar $71 \%$ kategori cukup tinggi. Dalam dimensi ini terdapat 1 indikator: (1) Mampu membuat tujuan perencanaan dalam perencanaan jangka pendek, menengah, dan jangka panjang. Dalam hal ini mahasiswa membuat perencanaan waktu yang efisien dan efektif dalam perencanaan jangka pendek, menengah dan jangka panjang karena perencanaan menentukan prioritas yang utama dan penentuan tujuan. Hal ini sesuai dengan pendapat Can (Cemaloğlu \& Filiz, 2010) bahwa perencanaan waktu terbaik berarti penentuan tujuan dan prioritas sebenarnya.

Selanjutnya dimensi terendah yaitu Dimensi Time Traps diperoleh persentase sebesar 69\% termasuk kategori cukup tinggi. Dalam dimensi ini terdapat 1 indikator: (1) Aktivitasaktivitas yang menggangu perencanaan kegiataan. Hal ini dapat menunjukan bahwa banyak aktivitas-aktivitas yang menggangu kegiatan perencanaan dan banyak membuang waktu yang tidak terprioritaskan. Hal ini sesuai dengan penelitian (Mahasneh, 2013) memperoleh data 2,96 ini menunjukan bahwa mahasiswa belom ada kesadaran untuk dapat mengatur waktu dan ketidakstabilan, tidak bertanggung jawab, ketidakpastian tujuan, tidak menentukan prioritas, distruction, penundaan, memikirkan detail adalah tantangan dalam proses terberat dalam manajemen waktu. 


\section{Hubungan Asertivitas dengan Keterampilan Manajemen Waktu dalam Penyusunan Skripsi pada Mahasiswa}

Hasil penelitian menunjukan adanya korelasi asertivitas dengan keterampilan manajemen waktu yang signifikan korelasi parsial (Uji-t) $t_{\text {hitung }} 3,64>t_{\text {tabel }}$ 1,65 dan hal ini menunjukan koefisien korelasi bertanda positif sebesar 0,264 yang berarti memiliki hubungan positif dan kategori rendah. Hal ini sesuai dengan penelitian yang dilakukan oleh (AM Ghiasvand, 2017) yang mengatakan bahwa keterampilan manajemen waktu dapat mengatasi tingkat kecemasan mahasiswa dan memperoleh ketegasan pada mahasiswa sesuai dengan penelitian di fakultas keperawatan.

Keterampilan manajemen waktu adalah kegiatan mengatur waktu dengan efektif dan efisien untuk mencapai tujuan tertentu secara maksimal dan menghindari penundaan. Keterampilan manajemen waktu ini secara umum dapat diartikan sebagai kegiatan yang harus dilaksanakan dengan menentukan prioritas agar mencapai tujuan yang sudah diharapkan dengan waktu yang sudah sesuai rencana. Hal ini sesuai dengan penelitian yang dilakukan (Muhlasin, 2019) yang mengatakan bahwa untuk mencapai suatu tujuan harus dapat mengelola watu secara efisien mengatur prioritas-prioritas. Cara untuk dapat mengutamakan prioritas dengan membuat daftar yang dan melakukan hal yang diutamakn terlebih dahulu. Percobaan ini terapkan dari prinsip Pareto dimana $80 \%$ dari prestasi dihasilkan dengan melakukan $20 \%$ usaha. Hal ini sesuai yang sudah dilakukan oleh Mahasiswa Universitas Negeri Jakarta yang sudah dapat membuat perencanaan sebesar $71 \%$, hal ini membuktikan bahwa mereka mampu bekerja dan dengan cerdas dan sederhana walaupun masih $69 \%$ mereka membuang waktu yang tidak penting. Mahasiswa tingkat akhir sebagai masa dewasa awal yang berusia 20-40 tahun menurut (Hurlock, 2003). Menurut (Santrock, 2007) orang dewasa muda termasuk kategori masa transisi mulai secara fisik, intelektual dan peran sosial. Fase dewasa adalah fase masa transisi yang akan dihadapkan oleh tuntutan dan peran yang baru menyebabkan mahasiswa harus mampu mengatur diri dan waktunya dengan baik ketika dihadapkan dunia baru yaitu dunia perkuliahan. Menurut (Santrock, 2007) dengan memiliki ilmu dan keterampilan seseorang akan mampu memecahkan suatu masalah dan mampu mengembangkan insiatif keratifnya. Oleh karena itu, perlunya mengatur diri dan waktu agar mencapai tujuan yang dicapai secara efisien dan meningkatkan kualitas kegiatan yang dilakukan dalam waktu yang terbatas dan tidak membuang waktu dengan hal yang tidak penting. Sehingga dalam keterampilan manajemen waktu masih terdapat $69 \%$ mahasiswa yang melakukan pemborosan waktu karena kurangnya ketegasan diri dalam mengerjakan skripsi.

Dalam penelitian ini ditemukan sebanyak $31,40 \%$ mahasiswa bekerja sebagai fulltime yang terdapat $67 \%$ persen mahasiswa tidak dengan tegas menolak untuk tidak bekerja dan memilih untuk lebih banyak menghabiskan waktunya di luar kampus. Seseorang yang tidak dapat mengatur waktu dengan baik menyebabkan pencapaian tujuan hidupnya akan memiliki keterhambatan dan cenderung tidak tegas dalam hidupnya. Hal ini berbanding terbalik jika seseorang dapat mengatur waktu dan terstruktur untuk pencapaian tujuannya, dapat diartikan individu tersebut tegas dan tepat untuk melakukan kegiataan dengan baik. Hal ini selaras dengan penelitian (Ahmed et al., 2016) bahwa orang yang asertif mampu mengatur waktu dengan baik. Sehingga mahasiswa yang kurang asertif dan tidak tegas dengan keputusannya tidak akan mampu untuk bisa mengatur waktu dengan baik dan akan cenderung lebih meluangkan waktu dengan kegiatan yang lain maka oleh sebab itu mahasiswa menjadi tidak percaya diri untuk menyelesaikan skripsinya. Mahasiswa yang tidak percaya diri atau cemas akan menjadi sulit untuk berpendapat kepada dosen dan takut untuk tidak dapat mengungkapkan pendapat pribadinya. Mahasiswa yang tidak dapat mengungkapkan pendapat pribadinya dan memiliki rasa takut dapat diartikan mahasiswa tersebut tidak asertif. Oleh karena itu, perlu adanya sikap asertivitas dalam diri untuk dapat melakukan penyesuaian diri dengan baik. Hal ini sesuai dengan penelitian (Nugroho \& Hartati, 2014) 45\% yang memiliki sikap asertivitas tinggi mampu menunjukan diri secara konsisten dalam mengemukan 
pendapat serta membantu teman tanpa adanya paksaan. Seseorang yang memiliki rasa percaya diri akan merasa bebas untuk dapat melakukan aktivitas yang diinginkannya. Hal ini sesuai dengan pendapat (Hendrati, 2014) yang mengatakan bahwa rasa percaya diri menjadi sebuah pendorong dan mempermudah kegiatan.

Berdasarkan perhitungan uji koefisien determinasi yang telah dilakukan dengan perhitungan koefisien determinasi $r_{y x_{1} x_{2}}=0,462$ makan $\mathrm{KD}=21,3 \%$ maka assertivitas berkontribusi terhadap keterampilan manajemen waktu sebesar $21,3 \%$ sedangkan sisanya $78,7 \%$ dipengaruhi oleh faktor lainnya. Dengan demikian, asertivitas mempengaruhi keterampilan manajemen waktu dalam penyusunan skripsi pada mahasiswa akhir. Sehingga dalam hal ini mahasiswa harus meningkatkan ketegasan diri dan percaya diri untuk dapat mengajukan pendapat dengan percaya diri dan tegas tanpa orang lain meragukannya. Oleh karena itu, orang yang asertif mampu mengatur waktu dengan baik dan tegas terhadap dirinya. Dengan signifikansi korelasi sebesar 0,264 termasuk taraf signifikan yang kuat. Sehingga dapat dikatakan assertivitas berhubungan dengan keterampilan manajemen waktu.

\section{Hubungan Motivasi dengan Keterampilan Manajemen Waktu dalam Penyusunan Skripsi pada Mahasiswa}

Hasil penelitian menunjukan adanya korelasi antara motivasi dengan keterampilan manajemen waktu yang signifikan korelasi (Uji-t) $t_{\text {hitung }} 6,74>t_{\text {tabel }}$ 1,65 dan koefisien korelasi bertanda positif sebesar 0,455 yang berarti memiliki hubungan positif dan kategori sedang. Penelitian ini serupa dengan (AM Ghiasvand, 2017) bahwa menunjukan hubungan yang signifikan dan positif antara manajemen waktu dan motivasi.

Keterampilan manajemen waktu adalah keterampilan yang berkaitan dengan tindakan yang harus dilakukan oleh individu agar memiliki waktu yang sudah direncanakan dengan baik dan bisa direalisasikan dengan baik pula. Menurut Atkinson (1990) manajemen waktu merupakan suatu keterampilan yang berkaitan dengan tindakan mengatur waktu dengan baik dan terencana. Mahasiswa tahun 2013 dan 2014 memasuki masa dewasa awal yang seharusnya sudah bisa mengatur waktu dengan baik untuk masa depannya. Menurut Santrock (2003) orang dewasa muda termasuk kategori masa transisi mulai secara fisik, intelektual dan peran sosial. Fase dewasa adalah fase masa transisi yang akan dihadapkan oleh tuntutan dan peran yang baru menyebabkan mahasiswa harus mampu mengatur diri dan waktunya dengan baik ketika dihadapkan dunia baru yaitu dunia perkuliahan.

Fase dewasa awal yang mulai memasuki dunia perkuliahan atau biasanya individu melakukan kegiatan lain selain kuliah setelah lulus dari sekolah menengah atas bukan lagi remaja yang bisa bebas melakukan tanpa merencanakan apapun. Fase dewasa awal ini harus mampu mengatur waktu dengan baik antara tugas utama dan waktu luang. Mahasiswa akhir adalah dewasa awal yang saat ini dihadapkan sedang menyusun skripsi mebutuhkan sebuah motivasi, baik dari internal maupun dari eksternal agar berjalannya penyusunan skripsi dengan baik. Hal ini sesuai dengan oleh penelitian (Vansteenkiste \& Maarten, 2009) seseorang memiliki pendorong dalam dirinya atau disebut dengan motivasi, seseorang tersebut dapat memiliki manajemen waktu yang tinggi. oleh karena itu, semakin tinggi motivasi internal maka semakin tinggi manajemen waktunya.

Berdasarkan perhitungan uji koefisien determinasi yang telah dilakukan dengan perhitungan koefisien determinasi $r_{y x_{2} x_{1}}=0,574$ maka KD $=32,9 \%$ maka motivasi terhadap keterampilan manajemen waktu sebesar $32,9 \%$ sedangkan sisanya $67,1 \%$ dipengaruhi oleh faktor lain. Menurut Hofer (2007) selain dari motivasi, ada faktor lain yang mempengaruhi keterampilan manajemen waktu yaitu, self regulation, pencapaian tujuan, persepsi dosen dll. Dengan signifikansi korelasi sebesar 0,455 termasuk taraf signifikan yang sedang. Sehingga dapat dikatakan motivasi berhubungan dengan keterampilan manajemen waktu. 
Hubungan antara asertivitas dan motivasi dengan keterampilan manajemen waktu dalam kategori sedang, dapat diartikan bahwa keterampilan manajemen waktu sangat diperlukan bagi mahasiswa untuk menyusun skripsi. Perlunya mengatur diri dan waktu agar mencapai tujuan yang dicapai secara efisien dan meningkatkan kualitas kegiatan yang dilakukan dalam waktu yang terbatas dan tidak membuang waktu dengan hal yang tidak penting. Hal serupa disampaikan dalam penelitian lain yang dilakukan oleh (Azhari, Mayangsari, 2015) menunjukkan hasil bahwa seseorang yang memiliki asertivitas yang tinggi, maka dapat melakukan penyesuaian diri dengan baik. Sehingga dalam keterampilan manajemen waktu bisa mengatur waktu dengan baik, tetapi saat ini masih terdapat $69 \%$ mahasiswa yang melakukan pemborosan waktu karena kurangnya ketegasan diri dalam mengerjakan skripsi. Hal ini selaras dengan penelitian Ahmed et al. (2016) bahwa orang yang asertif mampu mengatur waktu dengan baik. Seseorang yang tidak asertif cenderung kurang percaya diri terutama untuk berpendapat dan melakukan aktivitas lainnya. Hal ini sesuai dengan pendapat Hendrati (2014) yang mengatakan bahwa rasa percaya diri menjadi sebuah pendorong dan mempermudah kegiatan. Dengan seseorang yang memiliki pendorong dalam dirinya atau disebut dengan motivasi, seseorang tersebut akan memilki sikap yang tegas untuk dapat melakukan aktivitas yang diinginkannya berdasarkan rencananya.

\section{SIMPULAN DAN SARAN}

Hasil penelitian diketahui terdapat korelasi antara asertivitas dan motivasi dengan keterampilan manajemen waktu. Terdapat hubungan yang positif dan signifikan antara asertivitas dengan keterampilan manajemen waktu di dapat hasil yang signifikan korelasi parsial (Uji-t) $t_{\text {hitung }} 3,64>t_{\text {tabel }}$ 1,65 dan koefisien korelasi bertanda positif sebesar 0,264 yang berarti memiliki hubungan positif dan masuk ke dalam kategori rendah dan motivasi dengan keterampilan manajemen waktu didapat hasil yang signifikan korelasi (Uji-t) $t_{\text {hitung }} 6,74>\mathrm{t}_{\text {tabel }}$ 1,65 dan koefisien korelasi bertanda positif sebesar 0,455 yang berarti memiliki hubungan positif dan masuk ke dalam kategori sedang, dengan taraf signifikan $<0,05$. Hubungan positif menunjukan adanya hubungan asertivitas dan motivasi dengan keterampilan manajemen waktu dalam penyusunan skripsi. Hasil uji determinasi sebesar asertivitas berkontribusi terhadap keterampilan manajemen waktu sebesar $21,3 \%$ dan motivasi dengan keterampilan manajemen waktu sebesar $32,9 \%$ sedangkan sisanya ditentukan oleh variabel lain. Untuk peneliti selanjutnya diharapkan agar dapat menyempurnakan hasil penelitian ini dari sisi penyempurnaan item. Selain itu, diharapkan agar peneliti selanjutnya dapat menemukan variabel lain, selain assertivitas dan motivasi karena hasil penelitian yang dilakukan penelitimenunjukan bahwa terdapat variabel lain yang berhubungan dengan variabel keterampilan manajemen waktu.

\section{DAFTAR PUSTAKA}

Agusta, Yosiana N. (2015). Hubungan Antara Orientasi Masa Depan Dan Daya Juang Terhadap Kesiapan Kerja Pada Mahasiswa Tingkat Akhir Fakultas IImu Osisal Dan IImu Politik Di Universitas Mulawarman. EJournal Psikologi, (11), 369-381. https://doi.org/10.7868/s0032180x15110088

Ahmed, M. M., Abdelazeemel-hosany, W., \& Mohamed, N. (2016). Assessment of the Assertiveness and Job Satisfaction among High Qualified Nurses at Suez Canal University Hospitals Assessment of the Assertiveness and Job Satisfaction among High Qualified Nurses at Suez Canal University Hospitals. (February 2019).

Al'Ain, M. O., \& Mulyana, O. P. (2013). Pelatihan Asertif Untuk Meningkatkan Komunikasi Interpersonalanggota Hima (Himpunan Mahasiswa) Prodi Psikologi Fip UNESA. Jurnal IImu Manajemen (JIM), 1(3), 1-6. 
AM Ghiasvand. (2017). Relationship Between Time Management Skills And Anxiety and Academic Motivation Of Nursing Student in Tehran. Electron Phsycian.

Aritonang, M. (2019). Hubungan antara Happiness dengan asssertivitas mahasiswa yang sedang mengerjakan skripsi di Fakultas Hukum Univerisitas Diponegoro. Undergraduate Thesis. UNDIP EJournal System Portal.

Aslinawati \& Mintarti . (2017). Keterlambatan Penyelesaian Skripsi Mahasiswa Angkatan 2012 (Studi Kasus di Jurusan Ekonomi Pembangunan Fakultas Ekonomi Universitas Negeri Malang). Jurnal Pendidikan Ekonomi.

Aryaningrat, P. S. D., \& Marheni, A. (2014). Hubungan Antara Intensitas Quality Time Ibu dan Anak Dengan Asertivitas Remaja Di Kecamatan Pupuan, Kabupaten Tabanan.1(3), 1-11. Jurnal Psikologi Udayana.

Azhar, A., \& Ginting, N. K. (2014). Hubungan Antara Lingkungan Belajar Dan Manajemen Waktu Dengan Motivasi Menyelesaikan Studi. Analitika Jurnal Magister Psikologi UMA.

Azhari, Mayangsari, E. (2015). Siswa Tahun Pertama di SMP Relationship Between Assertive Behavir and Self-Adjustment in First Year Students at Junior High Sschool. Jurnal Ecopsy, 2(1), 20-25.

Britton, B.K., \& Tesser, A. (1991). Effects of Time Management Practices On College Grades. Educational Psychology Journal.

Budiyono, A. (2019). Efektifitas Konseling Kelompok Berbasis Karakter Masyarakat Banyumas dalam Meningkatkan Sikap Asertif. KOMUNIKA: Jurnal Dakwah Dan Komunikasi, 13(1), 107-120. https://doi.org/10.24090/komunika.v13i1.1926

Bustan, R., \& Shah, A. H. (2014). Motivasi Berjilbab Mahasiswi Universitas Al Azhar Indonesia (UAI). JURNAL AI-AZHAR INDONESIA SERI HUMANIORA, 2(3), 164. https://doi.org/10.36722/sh.v2i3.143

Cemaloğlu, N., \& Filiz, S. (2010). The Relation Between Time Management Skills and Academical Achievement of Potential Teachers. Journal of Chemical Information and Modeling, 33(9), 3-23. https://doi.org/10.1017/CBO9781107415324.004

Gea, A. A. (2014). Time Management: Menggunakan Waktu Secara Efektif dan Efisien. Humaniora : Jurnal Binus. 5(2), 777. https://doi.org/10.21512/humaniora.v5i2.3133

Hendrati, F. (2014). Hubungan Motivasi Berprestasi dan Harga Diri dengan Kinerja Guru SD di Malang Masyarakat Indonesia mempunyai harapan Sebaik-baiknya. Jurnal Psikologi Tabularasa, 9(2), 151-160.

Hurlock. (2003). Psikologi Perkembangan: Suatu Pendekatan Sepanjang Rentang Kehidupan.

Mahasneh, A. (2013). Attitudes University Students Towards Time Management Skills. European Journal of Social Sciences.

Mardelina, E., \& Muhson, A. (2017). Mahasiswa Bekerja Dan Dampaknya Pada AKtivitas Belajar Dan Prestasi Akademik. Jurnal Economia, 13(201-209).

Mediawati, E. (2010). Pengaruh Motivasi Belajar Mahasiswa dan Kompetensi Dosen Terhadap Prestasi Belajar. Dinamika Pendidikan.

Muhlasin. (2019). Manajemen Waktu Dalam Pendidikan: 13 Langkah Konseling Untuk Mencapai Keberhasilan. Jurnal Bimbingan Konseling Dan Islam.

Nugroho, A. Y. D., \& Hartati, S. (2014). Hubungan Antara Konsep Diri Dengan Asertivitas Pada Siswa SMA Mardisiswa Semarang. Empati, EJournal UNDIP 3(2), 1-13. 
Purwanto, N. A. (2010). Mengembangkan Perilaku Asertif Kepala Sekolah. Jurnal Internasional Manajemen Pendidikan, 4(02), 52-59.

Rahma, R. (2016). Hubungan antara Asertivitas dengan Prokrastinasi Akademik dalam Menyelesaikan Skripsi pada Mahasiswa Program PG PAUD Angkatan 2012 Fakultas Keguruan dan IImu Pendidikan Univesitas Riau. Jurnal Fakultas Keguruan Dan IImu Pendidikan.

Santrock, J. (2007). Remaja Edisi ke 1. Erlangga.

Sardiman. (2011). Interaksi dan Motivasi Belajar Mengajar. Jakarta.

Suardana, A. A. P. C. P., \& Simarmata, N. (2013). Hubungan Antara Motivasi Belajar dan Kecemasan pada Siswa Kelas Vi Sekolah Dasar di Denpasar Menjelang Ujian Nasional. Jurnal Psikologi Udayana, 1(1), 203-212. https://doi.org/10.24843/jpu.2013.v01.i01.p20

Sudarya, I. W., Bagia, I. W., \& Suwendra, I. W. (2014). Analisis Faktor-Faktor Yang Mempengaruhi Stres Pada Mahasiswa Dalam Penyusunan Skripsi Jurusan Manajemen Undiksha Angkatan 2009. E-Journal Bisma Universitas Pendidikan Ganesha, 2(1). Retrieved from http://ejournal.undiksha.ac.id/index.php/JJM/article/download/4309/3333

Sugiyono. (2015). Metode Penelitian Kuantitatif, Kualitatif dan R\&D. Bandung: Alfabeta.

Susilawati, Dwi. (2016). Hubungan Antara Komunikasi Interpersonal Dan Asertivitas Terhadap Perilaku Seks Pranikah Pada Remaja. Jurnal Psikologi Universitas Mulawarman.

Twenge. (2001). Changes in women's assertiveness in response to status and roles: A crosstemporal meta-analysis. Journal of Personality and Social Psychology, 81(1), 133-145.

Vansteenkiste \& Maarten. (2009). Motivation Profiles From a Self-Determination Perspective: The Quality of Motivation Matters. Journal of Educational Psychology. American Psychological Associaation.

Yong, F. L. (2010). A study on the assertiveness and academic procrastination of English and Communication student at a private university. American Journal of Scientific Research, 9.

Zin, M. K. M. (2001). Minat Dan Motivasi Pelajar Terhadap Mata Pelajaran Pendidikan Islam KBSM: Satu Tinjauan Ke Atas Pelajar-Pelajar Tingkatan 4 Di Sekolah Menengah Kebangsaan Tanjung Adang, Gelang Patah, Johor Bahru, Johor. Tidak Diterbitkan. 